\title{
タンク繰りにおける経路探索法*
}

\author{
石井 利昌 $\dagger \cdot$ 永持仁 $\ddagger$ 西垣 豊 $§ \cdot$ 高橋 健吾 $・$ 武田 真人 $\|$
}

\section{A Routing Algorithm on a Storage Tank System*}

\author{
Toshimasa IshiI ${ }^{\dagger}$, Hiroshi NAGAMOCHI ${ }^{\ddagger}$, Yutaka NisHigAKI ${ }^{\S}$, \\ Kengo TAKAHASHI and Makoto TAKedA ${ }^{\|}$
}

\begin{abstract}
In the petrochemical industry, we have been required to optimize a production schedule for the efficient management. Determining how to provide naphtha to the petrochemical plant is one of the most crucial problems in the optimization of such production scheduling. Typically, purchased naphtha, which is provided from the sea berth, is first stored temporarily in storage tanks, and after that, is provided to the plant, according to a predetermined production schedule. Then we are required to find pairwise disjoint routes between the sea berth and a tank, between two distinct tanks, or between a tank and the plant. In this paper, we formulate the problem of finding routes in a tank network as a problem of computing disjoint paths in a graph, and propose an algorithm for enumerating all sets of disjoint paths based on the graph theory. Our algorithm first constructs a tree-shaped data structure for each pair of prescribed vertices which represents all paths between the pair of verticcs, and then computes disjoint paths efficiently by traversing the tree-shaped data structures. We also evaluate the practical performance of our algorithm by conducting a computational experiment based on the case in Showa Denko K.K.
\end{abstract}

\section{1.はじめに}

石油化学事業は，エチレンプラントの製品であるエチ レン, プロピレン等が有機 (酢酸, アリルアルコール等) や合成樹脂 (ポリエチレン, ポリプロピレン) 等の誘導品 プラントの原料となって, 製品を産み出していく連産型 の事業である $[7,8]$. その中心であるエチレンプラントの 競争力が石油化学事業全体へ及ぼす影響が最も大きいこ

* 原稿受付 2004 年 9 月 16 日

†豊橋技術科学大学 工学部 Department of Engineering, Toyohashi University of Technology; 1-1 Tempaku-cho, Toyohashi city, Aichi 441-8580, JAPAN

‡京都大学 情報学研究科 Graduate School of Informatics, Kyoto University; Yoshida Honmachi, Sakyo, Kyoto city, Kyoto 606-8501, JAPAN

§北海道ビジネスオートメーション(株) Hokkaido Business Automation Co.,Ltd.; Chuo ward, Sapporo city, Hokkaido 060-0003, JAPAN

『中部日本電気ソフトウェア (株) NEC Software Chubu,Ltd.; 500-20 Komenokicho, Nisshin city, Aichi 470-0111, JAPAN

\| 昭和電工 (株) 石油化学事業部門 Showa Denko K.K.; 2 Nakanosu, Oita city, Oita 870-0189, JAPAN Key Words: algorithm, graph theory, routing.
とから，エチレンプラントの運転や生産計画の最適化は 重要な研究課題の一つである $[3,5,9,12]$.

エチレンプラント [11] では，原料であるナフサから熱 分解, 前蒸留, 圧縮, 蒸留の各工程を経て, エチレン, プロピレンなど種々の留分が生産される。これらの製品 の収率は, 分解温度等により若干の変動をさせることが できるが，その最大の決定要因はプラントに供給される ナフサの性状である。ナフサはその性状・購入価格の違 いからその種類を定めて取り扱われる. 効率的な生産活 動を行うためには, ナフサの種類・価格に加え, 製品価 格, 設備ネック等を考慮した, 適切なナフサ調達計画, プラントへのナフサ供給計画の立案が不可欠である.

ナフサは，主にナフサ船舶からシーバース (港)を通じ て，または近隣の石油会社からパイプラインを通じて購 入される Fig. 1参照). 購入されたナフサは, プラント に供給される前に, 一時的に複数のタンク (ナフサタン ク）に受け入れられる.プラントに供給されるナフサの 性状が，プラントの運転条件や製品収率に大きな影響を 与えるため，これらのナフサタンク間で異なる種類のナ フサの移し変え (移液), 混合などの操作を行うことで, 適切な性状のナフサを準備した後プラントに供給するこ とがしばしば有効となる。このとき，異なるナフサの移 


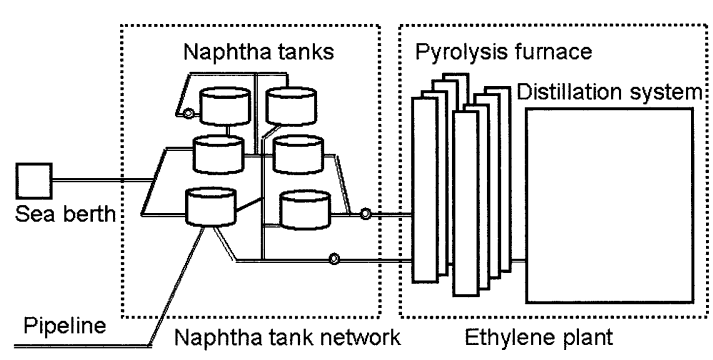

Fig. 1 A naphtha tank network which consists of a sea berth, tanks and an ethylene plant

液・供給の操作を行うためにはナフサタンク配管網にお けるそれらの送給経路は競合しないことが必要である。 たとえば，ある計画では，タンク Aに貯蔵されているナ フサをタンク B に移し変え, タンク Cに貯蔵されている ナフサをプラントに供給し, さらに, 外部から購入され たナフサをタンク Dに受け入れる, という操作を同時に 行うという場合が想定される。この計画を遂行する際に は，異なる種類のナフサが混ざることがないように，夕 ンク $\mathrm{A}$ からタンク $\mathrm{B} へ の$ 経路, タンク $\mathrm{C}$ からプラント への経路, シーバースからタンク Dへの経路という三つ の経路を互いに途中の配管や弁を共有しないように見つ け出す必要がある。この配管網における経路探索問題は, 日々のプラントの運用のみならず, 短期・長期の最適生 産計画を立案する際や配管の増設による配管網の送給能 力を算定する際にも重要な役割を果たす.

本論文では, 昭和電工 (株)における事例を基に, 経路 探索問題を解く効率的なアルゴリズムを提案する。経路 探索問題は 2. で述べるように計算量理論の観点からは効 率の良いアルゴリズムを設計するのが困難である問題で あり，通常のバックトラック手法に基づく経路の列挙方 法では少し問題の規模が大きくなると莫大な計算時間を 要する.そこで, 本論文では, 経路木保存アルゴリズム とよばれる解法を提案する。このアルゴリズムでは, 探 索に必要となるすべての経路を事前にすべて生成し，生 成された経路の集まりを経路木とよばれるコンパクトな データ構造の形にして格納しておく．実際の複数経路の 探索は，前処理において作成した経路木をたどることで 実行する。この解法では, 保持する経路木の領域量は問 題の規模に応じて指数関数的に大きくなり得る欠点があ るが，いったん保持に成功すれば，むだな探索ステップ の省かれた経路木上のみを探索することで高速に所望の 解を見つけることができる利点がある．実際の適用には， 現実の配管網の規模や配管網固有の性質等から必要な領 域量が実際上扱える範囲に収まることが鍵となる。本論 文では, 計算機実験を通して提案する経路木保存アルゴ リズムの有効性について検証する，なお，本論文で提案 する経路木保存アルゴリズムは, 実際に昭和電工 (株) で
配管網の経路探索システムに実用化されている。

本論文の構成は，以下の通りである．まず，2.で，ナ フサタンク配管網における経路探索問題をグラフ問題に 定式化する. 3.で, 経路探索問題に対する素朴なバック トラックアルゴリズムである分岐列挙アルゴリズムを紹 介した後, 本論文で提案する経路木保存アルゴリズムに ついて述べる. 4. では, 昭和電工 (株)における事例に 基づくグラフやいくつかのグラフのクラスを用いて, 提 案アルゴリズムと分岐列挙アルゴリズムの比較性能実験 を行い, 結果の考察を行う. 最後に, 5 . で本論文のまと め, 今後の課題について述べる.

\section{2. グラフ問題への定式化}

この章では，ナフサタンク配管網における経路探索問 題をグラフ問題へ定式化する方法について述べる.

\section{1 有向グラフとパス}

$G=(V, E)$ を， $V$ を節点集合， $E$ を枝集合とする有向 グラフとする $[1] .1$ 要素からなる集合 $\{x\}$ は単に $x$ と も書く. “C”は，真に包含することを意味し， “〕”は， “С”または“=”であることを意味する．節点 $u$ から節 点 $v$ へ向かう有向枝は, $(u, v)$ と表わされる. 有向グラフ $G=(V, E)$ において, 節点列 $P=\left[v_{1}, v_{2}, \ldots, v_{k}\right] \subseteq V$ は, 各 $i=1,2, \ldots, k-1$ について, $\left(v_{i}, v_{i+1}\right) \in E$ を満たすな らば，始点 $v_{1}$ から終点 $v_{k}$ へのパスとよばれる。ここで, $P$ は節点列とするが, 文脈によっては節点集合と考える こともある.パスは同じ節点を 2 度以上通らないとき単 純パスとよばれ, 本論文では, 特に指定しない限り, パ スとは，単純パスのことを意味する．与えられた 2 節点 $s, t$ に対し， $s$ を始点, $t$ を終点とするパスを $s, t$-パスと よぶ.グラフ $G$ において $s, t$-パスを 1 本求めるのは, $s$ から $G$ の深さ優先探索 $[10]$ を実行すれば線形時間で行 える.

2 組の始点終点ペア $\left\{s_{1}, t_{1}\right\},\left\{s_{2}, t_{2}\right\}$ が与えられたとき, $s_{1}, t_{1^{-}}$パス $P_{1}$ と $s_{2}, t_{2^{-}}$パス $P_{2}$ は, $\left(P_{1}-\left\{s_{1}, t_{1}\right\}\right) \cap P_{2}=\emptyset$ かつ $\left(P_{2}-\left\{s_{2}, t_{2}\right\}\right) \cap P_{1}=\emptyset$ あるとき, 互いに独立で あるという。

\section{2 配管網からグラフへの変換}

ナフサタンク配管網は, ナフサタンク, プラント, 購 入されたナフサを受け入れるためのポート, ナフサが通 る配管, 弁, 逆止弁 (一方向へしか通すことを許さない ための弁), ポンプから成る (Fig. 2 参照). Fig. 2 では, ポンプは $a$ のようれと四角を上下に並べた記号で表わ され, 弁は, $b$ のように三角形が向かい合うような記号 で表わされ，いずれにおいても両方向にナフサを流すこ とができる，逆止弁は，弁にさらに一つ三角形が加えら れた記号で表わされ，その余分な三角形が向く方向にし かナフサを流すことはできない. たとえば, Fig. 2 中の 逆止弁 $c$ において, ナフサは左から右への向きにしか流 れない. 


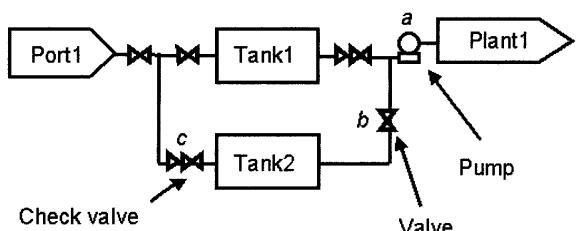

Tank network

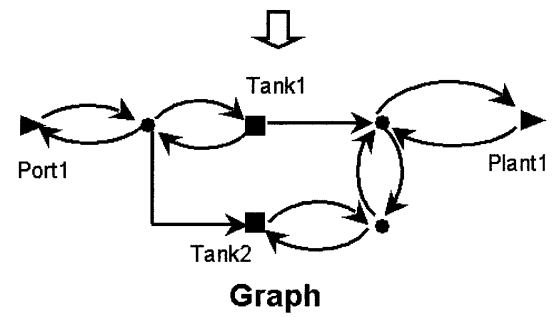

Fig. 2 A tank network and its graph representation

配管網を，次の通りにグラフへ置き換える。グラフの 節点に対応づけられるのは，ナフサタンク，プラント， ポート，配管で，グラフの枝に対応づけられるのは，弁， 逆止弁，ポンプである。このとき，弁，ポンプに対して は，接する二つの配管に対応する 2 節点を結ぶ有向枝が， 両方向にそれぞれ 1 本ずつ対応づけられ，逆止弁に対し ては，ナフサが流れる向きにのみ有向枝が 1 本対応づけ られる。

\section{3 経路探索問題}

ナフサタンク配管網上での経路探索問題は，配管網に おいて，始点終点ペア対が与えられたとき(始点終点の 候補は，タンク，シーバース，プラントである)，配管 網において，各始点終点ペア間の経路で互いに途中の 配管や弁を共有しないものを求める問題として定義さ れる。この問題は，与えられた有向グラフと 2 点対集合 $\left\{\left\{s_{i}, t_{i}\right\} \mid i=1,2, \ldots, p\right\}$ に対して，互いに途中の節点を 共有しない, $s_{i}, t_{i^{-}}$パス $P_{i}$ の集合を求める問題として定 式化できる。次の条件 (i),(ii) を満たすパスの $p$ 本のパス 集合 $\left(P_{1}, P_{2}, \ldots, P_{p}\right)$ を実行可能解とよぶ.

(i) $P_{i}$ は $G$ の $s_{i}, t_{i^{-}}$パス $(i=1,2, \ldots, p)$.

(ii) どの二つのパス $P_{i}, P_{j}, i \neq j$ も互いに独立である.

以下では，実行可能解をすべて列挙することを考える. すなわち問題は次のように記述することができる.

【問題 1】(経路集合探索問題) 入力: 有向グラフ $G=(V, E)$, 始点終点のペアの集合 $\left\{\left\{s_{i}, t_{i}\right\} \subseteq V \mid i=\right.$ $1,2, \ldots, p\}$.

出力: 実行可能解 (条件 (i),(ii) を満たす $p$ 本のパス集合) のすべての集合 $\mathcal{P}$.

実行可能解の総数は一般にグラフの節点数 $n$ の指数関数 個あり，さらに， $p=2$ の場合に一つの実行可能解を求め る問題ですら NP 困難であることが知られている $[2,6]$. そこで，ここでは現実の配管網から作られるグラフや始 点終点の選び方の特徵を利用した実用上有用なアルゴリ
ズムについて検討する。実際に現場の経路集合探索問題 に関して，以下の特徴が挙げられる。

(1) 経路探索のための始点，終点の候補となるのは, ナフサタンク，プラント，ポートであり，始点終点 ペアはあらかじめ決まっている。一度に要求される ペア数は 10 以下の数である.

(2) 配管網から得られるグラフは疎である $(|E| \leq 2|V|$ が成り立つ)。

\section{3. 経路探索アルゴリズム}

この章では，問題 $\mathbf{1}$ を解くためのアルゴリズムとして， 分岐列挙アルゴリズム，経路木保存アルゴリズムとよば れる二つのアルゴリズムを与える．分岐列挙アルゴリズ ムは，分枝限定法 [4] をグラフ探索に適用したバックト ラック法に基づく素朴な列挙方法で，特に目新しい手法 ではない。一方，本論文で提案する経路木保存アルゴリ ズムは，分岐列挙アルゴリズムの実行を高速化するため に経路木とよばれる特殊なデー夕構造を前処理で構築し ておく方法である.

\section{1 分岐列挙アルゴリズム}

始点終点のペア $\left\{s_{i}, t_{i}\right\}(i=1,2, \ldots, p)$ が $p$ 組与えられ たとき, 1 本の $s_{1}, t_{1}$-パス $P_{1}$ は $s_{1}$ を起点とする深さ優先 探索 [10] を用いて求めることができる．次に $s_{2}, t_{2}$-パス $P_{2}$ を求めるためには， $s_{2}$ を起点とする深さ優先探索を実 行すればよいが，このとき， $P_{1}$ の節点を訪問しているか どうかを調べながら探索することで $P_{2}$ を $P_{1}$ と独立にな るように選ぶことができる。以下同様に， $P_{1}, P_{2}, P_{3}, \ldots$ と順番にパスを固定していき，パス $P_{1}, \ldots, P_{i-1}$ が固定さ れたとき，パス $P_{i}$ を， $P_{1}, \ldots, P_{i-1}$ と独立になるように 求める。これを $i=p$ となるまで行えば, 実行可能解 (条 件 (i),(ii) を満たす $p$ 本のパス集合) が一つ求められる.

つぎにすべての実行可能解を生成するために分枝限 定法の考え方を用いる。第 1 パス $P_{1}$ から始め，順に $P_{2}, P_{3}, \ldots, P_{i-1}$ までパスが固定され，いま， $s_{i}$ を起点と する深さ優先探索により $s_{i}$ から一つパス $P_{i}$ が構築中で あるとする $\left(P_{i}\right.$ はまだ $t_{i}$ に達していない)，このとき， $P_{1}, \ldots, P_{i-1}$ を最初の $i-1$ 本のパスとし， $P_{i}$ を延長して $t_{i}$ に達するパスを第 $i$ パスとし，残りの $p-i$ 本のパスを 互いに独立となるように選ぶ実行可能解を考える。この ような実行可能解を $\left(P_{1}, P_{2}, \ldots, P_{i-1}, P_{i}\right)$ に整合する解と よび, $\left(P_{1}, P_{2}, \ldots, P_{i-1}, P_{i}\right)$ に整合する解のすべての集合 $\mathcal{P}^{\prime}$ を返す手続きを $\operatorname{Path}\left(P_{1}, P_{2}, \ldots, P_{i-1}, P_{i}\right)$ と書く.こ の手続きが用意されていれば，問題 $\mathbf{1}$ は次のアルゴリズ ム FindPathにより解くことができる。

アルゴリズム FindPath

入力: 有向グラフ $G=(V, E)$, 始点終点のペアの集合 $\left\{\left\{s_{i}, t_{i}\right\} \subseteq V \mid i=1,2, \ldots, p\right\}$.

出力: 実行可能解 (問題 1 の出力の (i),(ii) を満たすパス の $p$ 本のパス $\left.\left(P_{1}, P_{2}, \ldots, P_{p}\right)\right)$ のすべての集合 $\mathcal{P}$. 


\section{begin}

$\mathcal{P}:=\operatorname{Path}\left(P_{1}=\left[s_{1}\right]\right)$ を出力.

\section{end}

手続き $\operatorname{Path}\left(P_{1}, P_{2}, \ldots, P_{i-1}, P_{i}\right)$ は再帰的な構造によ り与えられる。いま， $P_{i}=\left[u_{i}^{1}=s_{i}, u_{i}^{2}, \ldots, u_{i}^{j}\right]$ としたと き, $\left(P_{1}, P_{2}, \ldots, P_{i-1}, P_{i}\right)$ に整合する解を漏れなく生成す ることを考える (手続き $\operatorname{Path}\left(P_{1}, P_{2}, \ldots, P_{i-1}, P_{i}\right)$ が呼び 出されたときの状態を Fig. 3 に示す). このとき， $P_{i}$ の現 在の終点 $u_{i}^{j}$ から出ている枝 $\left(u_{i}^{j}, u\right)$ をすべて 1 本ずつ選択 する (分枝操作). 選択した $\left(u_{i}^{j}, u\right)$ により現在のパス $P_{i}$ を $P_{i} \cup\{u\}$ に更新しても整合する解が存在しないことが 直ちにわかれば $\left(u_{i}^{j}, u\right)$ から先の探索を中止する (限定操 作). たとえば，Fig. 3 に扔いて破線の枝 $\left(u_{i}^{j}, u\right)$ は，すで に形成されているパス $P_{1}, P_{2}, \ldots, P_{i}$ 上の節点に接続して いるので，この節点 $u$ をするこの先の探索は中止され る。そうでない場合は, $u \neq t_{i}$ であれば, $P_{i}:=P_{i} \cup\{u\}$ とし, $\operatorname{Path}\left(P_{1}, P_{2}, \ldots, P_{i-1}, P_{i}\right)$ を呼び起こす. 以下に, $u=t_{i}$ となる場合の扱いを含めた詳細な手続きの記述を 与える.



Fig. 3 Illustration for paths $P_{1}, P_{2}, \ldots, P_{i-1}$ and $P_{i}$ when procedure $\operatorname{Path}\left(P_{1}, P_{2}, \ldots, P_{i-1}, P_{i}\right)$ is invoked, where $P_{i}=\left[u_{i}^{1}=s_{i}, u_{i}^{2}, \ldots, u_{i}^{j}\right]$.

手続き $\operatorname{Path}\left(P_{1}, P_{2}, \ldots, P_{i-1}, P_{i}\right)$

入カ: $s_{k}$ から $t_{k}$ へのパス $P_{k}, k=1,2, \ldots, i-1, s_{i}$ を始点 とするパス $P_{i}=\left[u_{i}^{1}=s_{i}, u_{i}^{2}, \ldots, u_{i}^{j}\right]$ (ただし $, P_{1}, P_{2}, \ldots, P_{i}$ のどの 2 本のパスも互いに独立であり, $\left.t_{i} \notin P_{i}\right)$.

出力: $P_{1}, P_{2}, \ldots, P_{i-1}, P_{i}$ に整合する解 $\left(P_{1}^{\prime}, P_{2}^{\prime}, \ldots, P_{p}^{\prime}\right)$ (すなわち以下の (iii)-(vi) を満たす実行可能解)の集合 $\mathcal{P}^{\prime}$.

(iii) 各 $P_{k}^{\prime}$ は $s_{k}, t_{k^{-}}$パス.

(iv) $P_{k}^{\prime}=P_{k}, k=1, \ldots, i-1$.

(v) $P_{i}^{\prime}$ は, $P_{i}$ を部分パスに持ち, $P_{i}^{\prime}$ の部分パス $\left(P_{i}^{\prime}-\right.$ $\left.P_{i}\right) \cup\left\{u_{i}^{j}\right\}$ は，どのパス $P_{j}^{\prime}, j \neq i$ とも独立である.

(vi) 各 $P_{k}^{\prime}, k=i+1, \ldots, p$ は, 他のどのパス $P_{j}^{\prime}$ とも独立 である。

\section{begin}

$\mathcal{P}^{\prime}:=\emptyset ;$

for 節点 $u_{i}^{j}$ から出ている各枝 $\left(u_{i}^{j}, u\right)$ に対し do もし，uが(a) $u \notin \bigcup_{k=1}^{i} P_{k}$ ，または

(b) $u=t_{i}$ かつ $u \in \bigcup_{k=1}^{i-1}\left\{s_{k}, t_{k}\right\}$ を満たせば, $u_{i}^{j+1}:=u, P_{i}:=P_{i} \cup\left\{u_{i}^{j+1}\right\}$ とし,

以下の (c-1)-(c-3)のうち該当する場合を実行.

(c-1) $u_{i}^{j+1} \neq t_{i}$ なら, $\mathcal{P}^{\prime}:=\mathcal{P}^{\prime} \cup$

$\operatorname{Path}\left(P_{1}, P_{2}, \ldots, P_{i-1}, P_{i}\right)$

(c-2) $u_{i}^{j+1}=t_{i}$ かつ $i \neq p$ なら, $\mathcal{P}^{\prime}:=\mathcal{P}^{\prime} \cup$

$\operatorname{Path}\left(P_{1}, P_{2}, \ldots, P_{i-1}, P_{i}, P_{i+1}=\left[s_{i+1}\right]\right) ;$

(c-3) $u_{i}^{j+1}=t_{i}$ かつ $i=p$ なら, $\mathcal{P}^{\prime}:=\mathcal{P}^{\prime} \cup$

$\left\{\left(P_{1}, P_{2}, \ldots, P_{p}\right)\right\}$

end $/ *$ for $* /$

$\mathcal{P}^{\prime}$ を返す。

$\operatorname{Path}\left(P_{1}, P_{2}, \ldots, P_{i-1}, P_{i}\right)$ は, $s_{k}, t_{k^{-}}$パス $P_{k}, k=1,2, \ldots$, $i-1, s_{i}, u_{i}^{j}$-パス $P_{i}, u_{i}^{j} \neq t_{i}$ (Fig. 3 では, 破線の枝, 黒 く塗りつぶされた節点，およびその黒い節点に入る枝す べてを除いた部分) に整合する解のすべての集合 $\mathcal{P}^{\prime}$ を返 すアルゴリズムである (厳密には, Path は, $P_{k}, k \leq i$ 同士の独立性がなくても動作することに注意されたい). 節点 $u$ の候補は，黒く塗りつぶされた節点で表わされて いる.

アルゴリズム FindPath の正当性を証明するために, 手続き $\operatorname{Path}\left(P_{1}, P_{2}, \ldots, P_{i-1}, P_{i}\right), i=1,2, \ldots, p$ の正当性 を帰納法により示す．まず， $i=p$ のときに，条件 (a) (b) を満たす枝がない場合，または条件 (a)(b) を満たす枝が $\left(u_{p}^{j}, t_{p}\right)$ のみである場合は, 手続き Path の正当性は明ら かである. よって, $\operatorname{Path}\left(P_{1}, P_{2}, \ldots, P_{i-1}, P_{i}\right)$ の正当性を 示すには, 手続き中で再州的に呼び出される処理が正しく 動作するという前提のもとで, $\operatorname{Path}\left(P_{1}, P_{2}, \ldots, P_{i-1}, P_{i}\right)$ が正しく動作することを示せば十分である。まず， $P_{i}$ に独立性の条件を破ることなく加えることのできる 節点 $u$ をすべて見つけ，そのような各節点 $u$ に対し， (c-1)-(c-3)のうち適切な手続きを行う. $u \neq t_{i}$ ならば, (c-1) で $\operatorname{Path}\left(P_{1}, P_{2}, \ldots, P_{i-1}, P_{i} \cup\{u\}\right)$ を再帰的に呼び

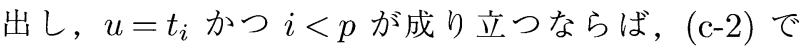
$\operatorname{Path}\left(P_{1}, P_{2}, \ldots, P_{i-1}, P_{i} \cup\{u\}, P_{i+1}=\left[s_{i+1}\right]\right)$ を再帰的 に呼び出すことで, $P_{k}, k \leq i-1, P_{i} \cup\{u\}$ に整合する 解すべてが $\mathcal{P}^{\prime}$ に加えられる. $u=t_{i}$ かつ $i=p$ ならば, $(\mathrm{c}-3)$ で得られたパスの $p$ 対 $\left(P_{1}, P_{2}, \ldots, P_{p} \cup\left\{t_{p}\right\}\right)$ が $\mathcal{P}^{\prime}$ に加えられる。 以上により, $\operatorname{Path}\left(P_{1}, P_{2}, \ldots, P_{i-1}, P_{i}\right)$ が 正しく動作することが証明される。

\section{2 経路木保存アルゴリズム}

我々の提案する経路木保存アルゴリズムは, 直接グ ラフ $G$ 上を探索しない. まず，前処理として，各ペア $\left\{s_{i}, t_{i}\right\}$ に対して, 始点 $s_{i}$ から終点 $t_{i}$ へのすべてのパス を表わす経路木 $T_{i}$ を作成する。経路木 $T_{i}$ とは以下の性 質を持つ根付き木である。

- $T_{i}$ の根は $s_{i}$ に対応し，葉節点はすべて $t_{i}$ に対応 する。

- $T_{i}$ 上において $s_{i}$ から葉節点へたどることで得られ 
る節点の順列が， $G$ 上の一つの $s_{i}$ から $t_{i}$ へのパス に一対一対応する。

-また, $s_{i}$ から $t_{i}$ への異なる二つのパス $P, P^{\prime}$ につい て, $s_{i}$ からある節点 $u$ までの節点の順列が共通であ れば, $P, P^{\prime}$ に対応する $T_{i}$ 上の二つの葉節点は必ず 節点 $u$ を根とする $T_{i}$ の部分木に含まれる.

Path は深さ優先探索に基ついていることから, 経路木 $T_{i}$ は，手続き $\operatorname{Path}\left(P_{i}=\left[s_{i}\right]\right)$ を実行し，生成した $s_{i}, t_{i^{-}}$ パスを木状に格納することで構築できる。

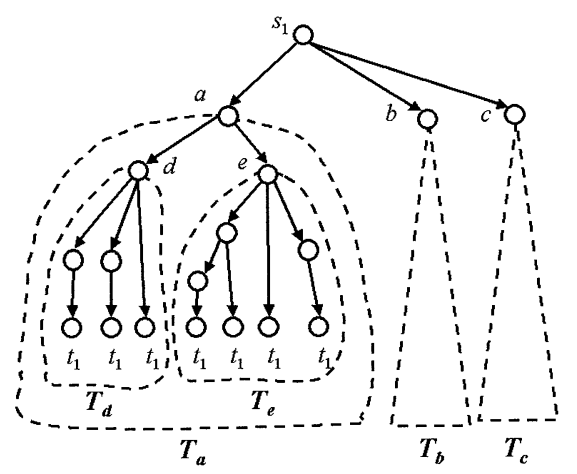

Fig. 4 A tree which represents all possible directed paths from $s_{1}$ to $t_{1}$

経路木 $T_{i}$ の性質から, $\operatorname{Path}\left(P_{i}^{\prime}=\left[s_{i}, \ldots, u\right]\right)$ によって 新たに見つかるパスに対応する葉節点はすべて， $T_{i}$ 上で は, 根 $s_{i}$ からパス $P_{i}^{\prime}$ を介してたどりつける節点 $u$ を根 とする部分木に含まれる. Fig. 4 に，すべての $s_{1}, t_{1}$-パ スを表わす経路木 $T_{1}$ の例を示す。ここで，部分木 $T_{a}$ は 節点列が $\left[s_{1}, a\right]$ から始まるすべての $s_{1}, t_{1}$-パスを表現す る. 同様に, $T_{b}, T_{c}, T_{d}, T_{e}$ は，節点列がそれぞれ $\left[s_{1}, b\right]$, $\left[s_{1}, c\right],\left[s_{1}, a, d\right],\left[s_{1}, a, e\right]$ から始まるすべての $s_{1}, t_{1}$-パス を表している。

経路木保存アルゴリズムは，FindPathを前処理で得 られた経路木集合上で適用することにより所望のパス集 合を求める. 分岐列挙アルゴリズムでは, その時点で固 定しているパス集合のみを保持しているだけで所望のパ ス集合を計算できる。これに対し，経路木保存アルゴリ ズムは，経路木集合を読み込んでから探索を行うため， 各ペア間に存在するパス数が多ければ多いほど領域量を 消費するという欠点があるが，いったん，経路木構造が 格納できれば，余分な情報を前処理で取り除いているた め, 高速に所望のパス集合を構築できる利点がある.

\section{4. 実験結果}

経路木保存アルゴリズムと分岐列挙アルゴリズムの性 能を計算時間とメモリ消費量の観点から比較するため, 昭和電工 (株) の配管図から変換したグラフ (以下, SDK グラフとよぶ), 格子状グラフ, クラスタグラフとよば れるグラフの 3 種類を用いて計算機実験を行った。実 験環境は, OS: Windows2000, CPU: Intel Pentium4 2.00GHz, Memory: 512MB である. なお，以下に示す
図では，分岐列挙アルゴリズムと経路木保存アルゴリズ ムを，それぞれFindPath，FindPath-Tree と表わす。

\subsection{SDK グラフ}

SDK グラフの節点数, 枝数は, ともにおよそ 100 程度 である，始点終点ペア数に関しては，実際の運用実績に 従い，1〜6に設定した. それぞれのペア数に対し，問題 例 (始点終点ペアの取り方)を 10 パターンずつ作り, 計 算時間，メモリ消費量の平均をとっている。 また， 7 以 上のペア数の計測については, 分岐列挙アルゴリズムの 実行に莫大な時間がかかった。 また，経路木保存アルゴ リズムに必要な経路木集合はあらかじめ生成してあると する．経路木集合を生成するのに要した時間は 4 秒程度 であった

Fig. 5 は, 計算時間の比較を表わしている.ペア数が 増加するにつれて，分岐列挙アルゴリズムの計算時間が 指数関数的に増えていることがわかる. 一方で, 経路木 保存アルゴリズムは，ペア数が増えても計算時間の増分 は極めて少ない．ただし，2ペア程度であれば二つのア ルゴリズムの計算時間に大きな差はない.

Fig. 6 は,メモリ消費量の比較を表わしている．縦軸の メモリ消費量は, 木集合に使用されている節点数で評価 している。経路木保存アルゴリズムのメモリ消費量は, ペア数が増えていくに従って，指数関数的に増加してい る。一方で，分岐列挙アルゴリズムではメモリ消費量の 変動はほとんど見られない。ただし，2ペア程度であれ ば二つのアルゴリズムのメモリ消費量に大きな差はない。

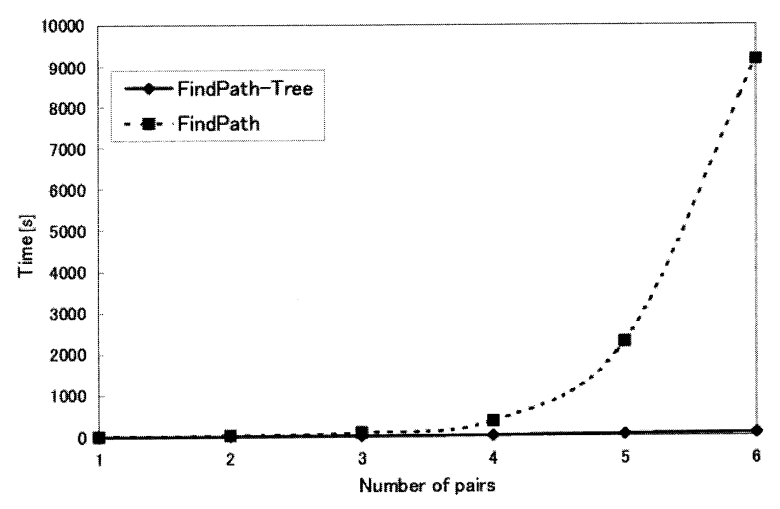

Fig. 5 Run times of algorithms FindPath and FindPathTree for SDK graphs

\section{2 格子状グラフ}

つぎに，SDK グラフと同程度に疎なグラフの一例と して, Fig. 7 のうに縦の節点数が $n$, 横の節点数が $n$ の格子状のグラフを用いた．各枝は，基本的には右か下 にしか進めない一方向の枝だが，10\%の確率で左右，ま たは上下に向かう両方向の枝が張られている.またそれ とは別に，各 2 節点間において，10\%の確率で枝が張ら れないようにしている。このグラフにおける始点終点の ペアに関して，始点は上端と左端からランダムに選び， 


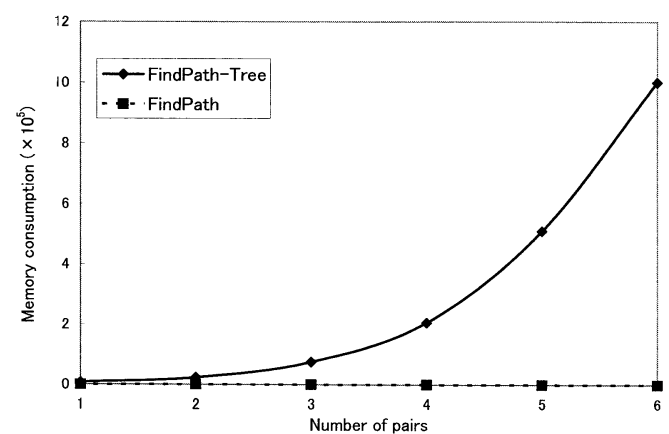

Fig. 6 Memory spaces used by algorithms FindPath and FindPath-Tree for SDK graphs

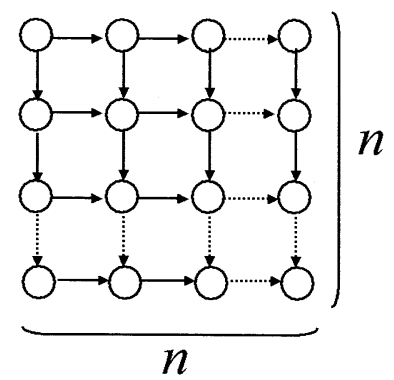

Fig. 7 An $n \times n$ grid graph

終点は下端と右端からランダムに選んでいる。

始点終点ペアの数を 3 に固定し, グラフのサイズを それぞれ $n=4,8,12,13,14$ とした場合に変化させた。そ れぞれのグラフサイズで 10 パターン測定し，その平均 を取っている. SDK グラフの規模は，格子グラフでは $n=12$ の場合に相当する. 本実験では, $n=14$ の場合, 経路木保存アルゴリズムでは， 3 ペアの経路を求めるこ とができなかった．また，これ以上のペア数の計測は分 岐列挙アルゴリズムで莫大な時間がかかるため計測を 行っていない．また，経路木保存アルゴリズムではあら かじめ必要な経路木集合を生成してある. 経路木集合を 生成するのに今回要した時間は以下の Table 1 の通りで ある。

Table 1 Run time for constructing a set of trees as the preprocess of algorithm FindPath-Tree in grid graphs

\begin{tabular}{|c|c|c|c|c|}
\hline Graph size & $4 \times 4$ & $8 \times 8$ & $12 \times 12$ & $13 \times 13$ \\
\hline Time [s] & 0.764 & 2.866 & 5.788 & 10.023 \\
\hline
\end{tabular}

計算時間の比較では，グラフサイズの増加によって分 岐列挙アルゴリズムは指数関数的に増加している (Fig. 8 参照). $n=12$ から経路木保存アルゴリズムと差が出始 めている. 前述の通り, SDKグラフの規模がちょうどこ の辺りに該当し, 経路木保存アルゴリズムがSDK グラ

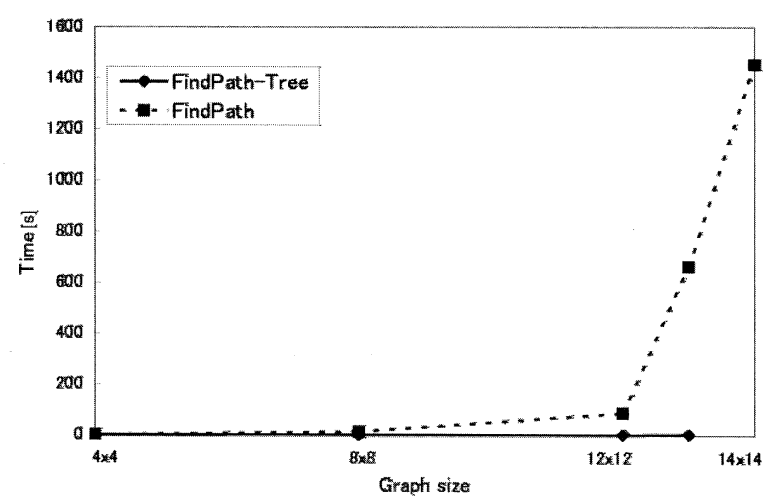

Fig. 8 Run times of algorithms FindPath and FindPathTree for an $n \times n$ grid graph with 3 pairs

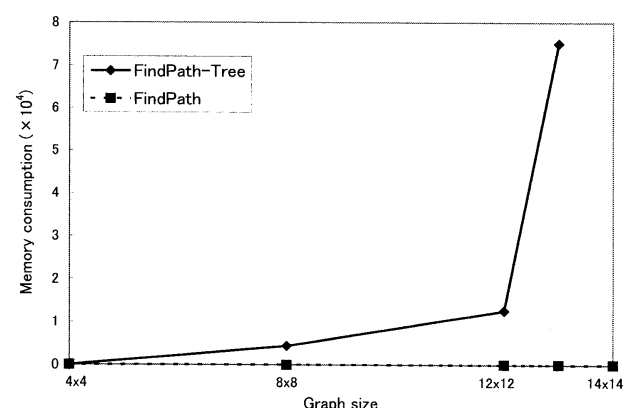

Fig. 9 Memory spaces used by algorithms FindPath and FindPath-Tree for an $n \times n$ grid graph with 3 pairs

フでは有効であることがわかる.

メモリ消費量の比較では, グラフサイズの増加に伴い, 経路木保存アルゴリズムのメモリ消費量が指数関数的に 増加し, $n=14$ の場合の測定は行えなかった (Fig. 9 参 照). しかし，メモリ消費量が少ない分岐列挙アルゴリズ ムにおいては実行することができた. よって, $n$ が14〜 20 程度の格子グラフに対しては分岐列挙アルゴリズムの 方が有効であるといえる。

つぎにグラフのサイズを $n=12$ に固定し，ペア数を $3,6,9,12$ と変化させたときの計算時間とメモリ消費量 を調べた.ペア数が 12 のときの分岐列挙アルゴリズム の計算時間は莫大な時間がかかるため計測していない. Fig. 10 によると, 分岐列挙アルゴリズムでは, これまで の結果と同様にペア数の増加に従って指数関数的に計算 時間が増加している．9ペアの結果を求めるのに，3時 間 30 分ほどかかる. また, 経路木保存アルゴリズムは その場合でさえ 4 分弱で計算を終えている，ただ，12ぺ アのときでは経路木保存アルゴリズムでも 26 分程度か かっている.

メモリ消費量の比較に関しては, Fig. 11 に示されて いる通り，分岐列挙アルゴリズムでは，9ペアのときで もほとんどメモリを消費していないのに対し, 経路木保 存アルゴリズムはペア数に比例してメモリ消費量が増加 




Fig. 10 Run times of algorithms FindPath and FindPath-Tree for a $12 \times 12$ grid graph

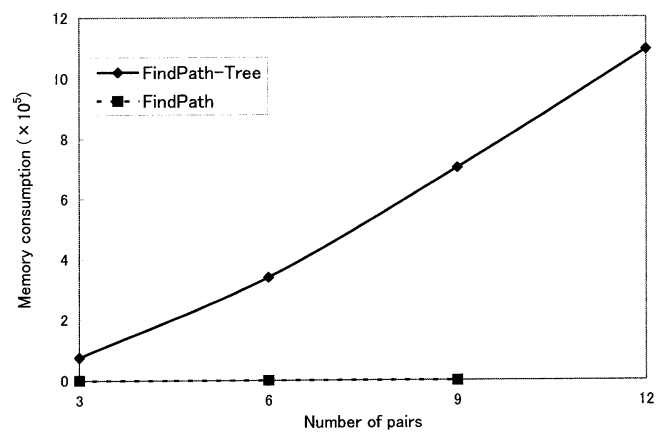

Fig. 11 Space complexity (a $12 \times 12$ grid graph)

している。これは，ペア数が 1 増えるたびに，保持する 経路木が一つ増え，またどのペア間でもそれほど経路本 数の差がないためである。本来であれば SDK グラフに おけるメモリ消費量でもこのような形を取るはずである が, SDK グラフでは, 始点終点ペア間の経路数がペア によってかなり異なるため, Fig. 6 のような結果になっ たと思われる。

\section{3 クラスタグラフ}

$n \times n$ グラフは 2 次元的な構造を持つが，それとは別 な構造を持つグラフとして，クラスタグラフとよばれ る，密な部分と疎な部分が存在するグラフに対して実験 を行った。ここで扱われるクラスタグラフとは，Fig. 12 のように，節点集合 $V$ を $\left\{V_{1}, V_{2}, \ldots, V_{t}\right\}$ に分割し，各 $V_{i}$ が誘導する部分グラフを密とし，異なる $V_{i}, V_{j}$ 間を接続 する部分を疎とすることで得られるグラフのことをいう.

詳細な作り方は以下の通りである。まず各節点を，い ずれかの $V_{i}$ にランダムに割り振る．つぎに，すべての 2 節点間に確率 $\rho_{2}$ で枝を張る。最後に，各枝に対し，そ の両端点が同じ $V_{i}$ に含まれていなければ確率 $\rho_{1}$ で枝を 残す。

本実験では，節点数を 50 , ペア数を 3 ，分割数を 10 に 固定し, 枝を張る確率 $\rho_{2}$, 異なる $V_{i}, V_{j}$ 間を結ぶ枝を残 す確率 $\rho_{1}$ を変化させて実験を行った，具体的には， $\rho_{1}$ を

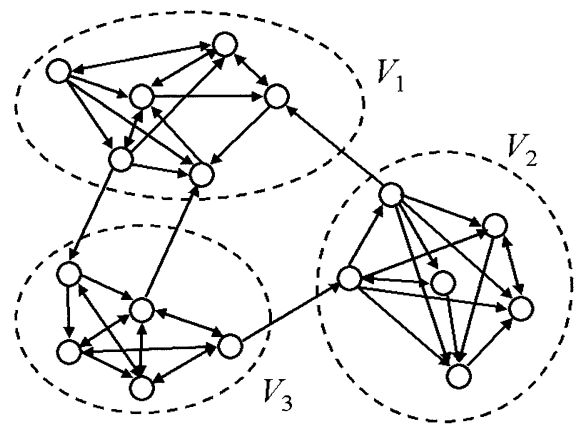

Fig. 12 A clustered graph

$10 \%$ に固定し， $\rho_{2}$ を $20 \%, 30 \%, 40 \%, 50 \%, 60 \%, 70 \%$ に変化させる場合と， $\rho_{2}$ を $30 \%$ に固定し， $\rho_{1}$ を $10 \%$ ， $20 \%, 30 \%$ に変化させる場合に分けて，測定を行った．そ れぞれ 10 パターン測定し，その平均を取っている。な お， $\rho_{2}$ が $70 \%$ の場合，分岐列挙アルゴリズムでは莫大な 時間を要するため測定していない. また, 経路木保存ア ルゴリズムについては，あらかじめ必要な経路木集合を 生成してある。経路木集合を生成するのに要した時間は, 以下の Tables 2, 3 の通りである.

Table 2 Run time for constructing a set of trees as the preprocess of algorithm FindPath-Tree in clustered graphs with $\rho_{1}=10 \%$

\begin{tabular}{|c|c|c|c|c|}
\hline \multicolumn{2}{|c|}{$\rho_{2}(\%)$} & 20 & 30 & 40 \\
\hline \multicolumn{2}{|c|}{ Time $[\mathrm{s}]$} & 0.015 & 0.015 & 2.123 \\
\hline 50 & 6 & 0 & 70 & \\
\hline 3.786 & 16. & 865 & 42.873 & \\
\hline
\end{tabular}

Table 3 Run time for constructing a set of trees as the preprocess of algorithm FindPath-Tree for clustered graphs with $\rho_{2}=30 \%$

\begin{tabular}{|c|c|c|c|}
\hline$\rho_{1}(\%)$ & 10 & 20 & 30 \\
\hline Time $[\mathrm{s}]$ & 0.015 & 2.186 & 5.968 \\
\hline
\end{tabular}

まず， $\rho_{1}$ を $10 \%$ に固定した場合の結果について考察 する. Fig. 13 は， $\rho_{2}$ を変化させた場合の計算時間の変 化を表わしている．分岐列挙アルゴリズムでは， $\rho_{2}$ が $50 \%$ を超え始めると急に計算時間が増加している．また， $\rho_{2}$ が $70 \%$ のをは経路木保存アルゴリズムでも 30 分程 度かかっており，どちらの方法でも， $\rho_{2}$ の増加に伴い計 算時間が指数関数的に増加することがわかる.

一方，Fig. 14 は，メモリ消費量の変化を表わしてい る.メモリ消費量に関しては, 経路木保存アルゴリズム で， $\rho_{2}$ が50\%を超える辺りから大きく変化しており， $\rho_{2}$ の増加に伴い指数関数的に消費量が大きくなっているこ とがわかる. 分岐列挙アルゴリズムに関しては, $\rho_{2}$ の值 に関わらずメモリ消費量の変化は微小である. 


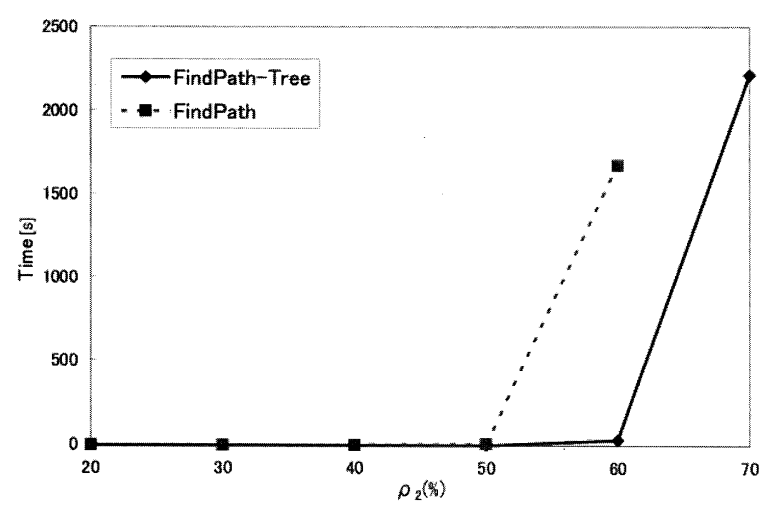

Fig. 13 Run times of algorithms FindPath and FindPath-Tree for a clustered graph with 3 pairs, 50 vertices and $\rho_{1}=: 10 \%$

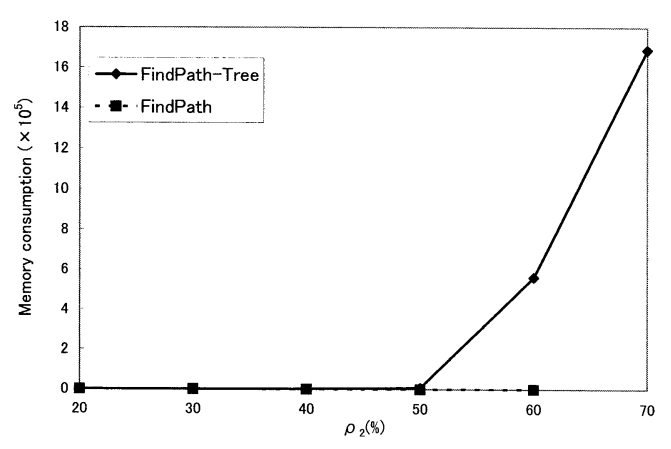

Fig. 14 Memory spaces used by algorithms FindPath and FindPath-Tree for a clustered graph with 3 pairs, 50 vertices and $\rho_{1}=10 \%$

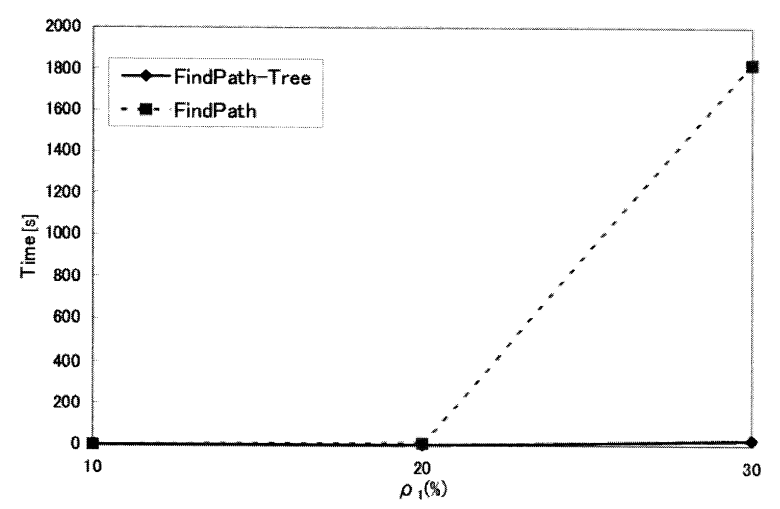

Fig. 15 Run times of algorithms FindPath and FindPath-Tree for a clustered graph with 3 pairs, 50 vertices and $\rho_{2}=30 \%$

つぎに, $\rho_{2}$ を $30 \%$ に固定した場合の結果について考察 する. Fig. 15, Fig. 16 は，それぞれ $\rho_{1}$ を変動させたと きの計算時間およびメモリ消費量の変化を表わしている.

$\rho_{1}$ を固定した場合と同様に，分岐列挙アルゴリズムに ついては計算時間が, 経路木保存アルゴリズムについて はメモリ消費量が， $\rho_{1}$ の増加に伴い指数関数的に増加し ていることがわかる。

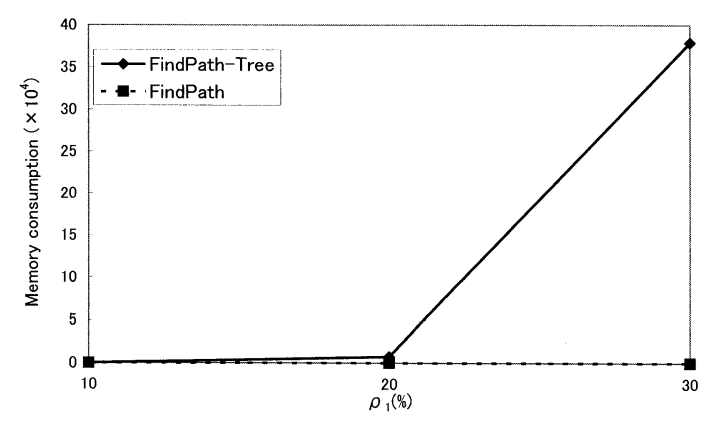

Fig. 16 Memory spaces used by algorithms FindPath and FindPath-Tree for a clustered graph with 3 pairs, 50 vertices and $\rho_{2}=30 \%$

これらの結果は， $\rho_{1}$ または $\rho_{2}$ が増えることで，指定 された始点終点間に存在する経路数が増加することが原 因であると推測される。

\section{5. おわりに}

本論文では, 始点終点対の集合が与えられたとき, 指 定された始点終点間の互いに独立なパスの組合せすべて を求める, 経路木保存アルゴリズムとよばれるアルゴリ ズムを提案した．計算機実験により，素朴なアルゴリズ ムである分岐列挙アルゴリズムとともに性能評価を行い, 両アルゴリズムについて，実用的に解ける範囲のグラフ のサイズや始点終点ペア数を調査した.

昭和電工 (株)における事例では, 要求されている節 点数 100 程度, 枝数 100 程度, ペア数 6 程度であり, 経 路木保存アルゴリズムはこのような場合には効率よく動 作することがわかった．昭和電工 (株)における従来法は 担当者の経験に基づくもので計算機上にシステム化され ていなかった。 そのため, 使用可能な経路の確認にかな りの時間を要していた。また，配管網上に確保可能な経 路が存在していながら担当者がそのような経路を思いつ かない場合, 結果としてナフサの効率的な送給に利用で きず，収益を減少させていた。現在, 昭和電工(株)の経 路探索システムでは, 経路木保存アルゴリズムが実際の 日々の運用に使用され, 経路確保の高速確認や運転条件 による経路の最適な変更が行えるようになり，この結果 が収益の増加につながっている，また，このアルゴリズ ムは，すべてのパスの組合せを列挙するため，なるべく 使用したくない枝 (弁)に対してコストをつけることで， 実行可能解に順位付けを与えて出力することも可能であ り, 現場の要求に応えやすい柔軟なアルゴリズムといえ る.たとえば，すべての枝にコスト 1 をつけることで， 最短距離の経路を選択することが可能になる．実際に昭 和電工 (株)の経路探索システムに組み込まれている経路 木保存アルゴリズムでは枝コストを用いて弁の使用頻度 や経路長等が考慮されている。 
また，本論文では，昭和電工 (株)に扔ける事例のほか にも，格子状グラフ，クラスタグラフとよばれるグラフ においても計算機実験を行い，ほかへの適用の可能性を 探った。実験結果からは，存在しうるパスの組合せ数の 増加に従い，経路木保存アルゴリズムについてはメモリ 消費量が，分岐列挙アルゴリズムについては計算時間が， 増加する傾向があることがわかった.

今後の課題としては他の一般的なグラフに対しての性 能評価，また計算時間と領域量のトレードオフを制御す ることのできるアルゴリズムの開発が挙げられる.

\section{参考文献}

[1] 浅野: 情報と構造, 日本評論社 (1994)

[2] S. Fourtune, J. Hopcroft and J. Wyllie: The directed subgraph homeomorphism problem; Theoretical Computer Science, Vol. 10, pp. 111-121 (1980)

[3] 藤田, 江本, 竹下, 佐中: 化学産業に扔ける最適化技術 の適用; オペレーションズ・リサーチ, Vol. 48 , No. 8, pp. 549-554 (2003)

[4] 茨木, 福島: 最適化の手法, 共立出版 (1993)

[5] 情報システムと情報技術辞典編集委員会: 石油化学コン プレックスにおける生産管理システム; 情報システムの 実際, Vol. 3, pp. 92-99 (2003)

[6] Y. Perl and Y. Shiloach: Finding two disjoint paths between two pairs of vertices in a graph; Journal of the Association for Computing Machinery, Vol. 25, No. 1, pp. 1-9 (1978)

[7] 石油化学工業協会: 石油化学ガイドブック (2002)

[8] 石油化学工業協会: 石油化学工業の現状 2003 年 (2003)

[9] 竹下, 朝倉, M. Turkay, 藤田: 大規模石油化学工場に押 ける生産計画最適化システム; 2000 年度日本オペレー ションズ・リサーチ学会秋季研究発表会アブストラクト 集, pp. 216-217 (2000)

[10] R. E. Tarjan: Depth-first search and linear graph algorithms; SIAM Journal on Computing, Vol. 1, pp. 146-160 (1972)

[11] 安波: エチレンプラント; 化学工業, 第 47 巻, 第 3 号, pp. 188-191 (1983)

[12] A. J. Young, 増淵: プロセス制御系の設計, コロナ社 (1956) 